\title{
EFFECT ON A PEAT SOIL OF APPLICATION OF SUPER- PHOSPHATE AT VARIOUS RATES
}

\author{
Armi KaIla \\ University of Helsinki, Department of Agricultural Chemistry
}

Received December 15, 1958

The effect of a fertilizer on a soil and on plants growing in it is not only limited to the influence of the main nutrient applied. Usually, the soil receives in the fertilizer also other nutrients and compounds the effect of which cannot be neglected. In addition to these it should be remembered that a better supply of some nutrient, particularly if the soil has been deficient in it, may markedly affect the uptake of other nutrients by the crop plants. A larger amount of root and stubble remaining in the soil after a higher yield has been harvested also adds to the indirect effects of a certain fertilizer.

Owing to the large mass of soil in a ploughing layer and to the fact that the soil tends to be well buffered in regard to several of its properties, these effects on the soil in the field are, usually, discernible only after a prolonged treatment with the fertilizer in question. In Finland there are relatively few field experiments in which the plots have been treated according to the same fertilization plan for more than twenty years. Among trials of this type there are some field experiments at the Leteensuo Experiment Station of the Suoviljelysyhdistys (Peat Cultivation Society). In one of these, started in 1923, superphosphate has been continuously applied at three different rates every year.

On the basis of material originating from this field experiment VaLdmaA (7) made a study of the effect of long-time application of superphosphate on the quality of humic matter. In the variously treated samples he found distinct differences in several of the properties of the fractions of organic matter, although, generally, these differences were unexpectedly small.

The author (4) has studied the effect of superphosphate on the mobilization of nitrogen in this trial. Late in autumn 1957 the mineral nitrogen content of the soil was to a depth of $70 \mathrm{~cm}$ highest in the plots treated with the highest amounts of superphosphate. The positive effect of the lower superphosphate applications 
could be found in the ploughing layer. The amounts of nitrogen in the hay yields harvested in the previous summer also appeared to be the higher the larger the quantities of superphosphate applied annually.

The primary object of this paper is the study of the effect of superphosphate on the phosphorus conditions of the peat soil in question. Attention is also paid to some other nutrients, particularly to potassium.

\section{Material}

The fen on which the field trial was started in 1923 had been under virgin conditions a wooded swamp with herbs and grasses the growth of which is reported to have been luxuriant (2). It was reclaimed in 1921. In 1923 it was clayed with $200 \mathrm{~m}^{3} /$ ha.

All the plots received annually equal amounts of $40 \%$ potash fertilizer. In the first seven years this was applied in amounts of $200 \mathrm{~kg} / \mathrm{ha}$. As from 1930 the amount was increased to $250 \mathrm{~kg} / \mathrm{ha}$, but during war-time only $100-150 \mathrm{~kg} / \mathrm{ha}$ could be applied. In the subsequent years the quantities of $40 \%$ potash fertilizer varied from 200 to $300 \mathrm{~kg} / \mathrm{ha}$.

The annual phosphate treatments of the plots analyzed in the present study were as follows:

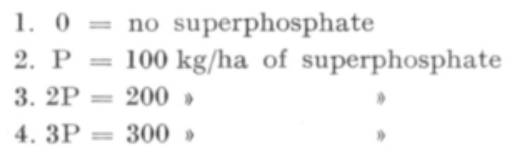

All the treatments were in four replicates. The plots were $45 \mathrm{~m}^{2}$.

With a few exceptions the experimental crops were grain in three successive years, followed by a timothy ley for five years. In 1957, however, a hay crop was harvested from the ley which by then was nine years old.

Soil samples were collected in September 1956 from the ploughing layers of all the plots. Hay samples were taken from the yield harvested in July 1957. All the samples were dried at room temperature and ground in a Wiley mill.

\section{Methods}

The $\mathrm{pH}$-values were measured in water suspension and in $1 \mathrm{~N} \mathrm{KCl}$ suspension (1: 2.5) using a Beckman $\mathrm{pH}$-meter with a glass electrode.

Total nitrogen was determined by a somewhat modified Kjeldahl-procedure which also allowed the estimation of total phosphorus and total potassium in the same digest.

The extractable cations were determined by shaking the soil samples in $1 \mathrm{~N}$ ammonium chloride in the ratio of 1: 50 for one hour. The stotals amounts of the cations were analyzed from the ash dissolved in hydrochloric acid. Calcium and magnesium were determined by the versenate titration, calcium and potassium by the flamephotometer. 
Inorganic phosphorus was extracted from the soil samples by successive treatments with $4 \mathrm{~N}$ sulphuric acid and $0.5 \mathrm{~N}$ sodium hydroxide. After an extraction of $1 \mathrm{~g}$ of soil with $25 \mathrm{ml}$ of sulphuric acid at room temperature for 18 hours the well washed sample was treated with $100 \mathrm{ml}$ of the alkali at room temperature for 18 hours and then with $50 \mathrm{ml}$ of alkali at $90^{\circ} \mathrm{C}$ for 3 hours. One tenth of the acid extract and of the combined alkali extracts were mixed, $5 \mathrm{ml}$ of $1 \mathrm{~N}$ sulphuric acid was added, and the flocculated organic matter was separated by filtration. The inorganic phosphorus in the filtrate was determined.

The organic phosphorus was calculated as being the difference of the total phosphorus in Kjeldahl-digest and the inorganic phosphorus determined by the acid-alkali extraction.

Phosphorus in the hay samples was fractionated by the authors's simplified method (3).

The method introduced by TERÄsvuORI (6) was employed in the estimation of the phosphorus condition in the soil samples. Instead of the common Neubauer method a modification in which turnip rape seedlings were grown was used for the determination of plant available phosphorus. The easily extractable phosphorus was estimated by the standard procedure of BRAY AND KuRTz (1) in which the ratio of soil to solution was changed to $1: 10$.

\section{Crop yields}

According to the data reported by HiRvensalo (2) the average annual yields per hectare from the beginning of the trial in 1923 to the year 1944 were in fodder units:

$\begin{array}{cccc}0 & \mathrm{P} & 2 \mathrm{P} & 3 \mathrm{P} \\ 1034 & 2349 & 2597 & 2575\end{array}$

In the first years the differences between the treatments were not very distinct, but as early as the third year the inferiority of the plots without phosphate became significant, also the plots treated with $100 \mathrm{~kg} / \mathrm{ha}$ of superphosphate gave lower yields than those with higher applications. The quality of the crop also seemed to be better in plots treated with the higher amounts of superphosphate than especially, in the untreated ones. This may be seen e.g. in the botanical composition of the hay: the percentages of timothy in the hay from the five year old ley in 1937 were $0,31,78$, and 73 in the plots treated with $0,100,200$, and $300 \mathrm{~kg} / \mathrm{ha}$ of superphosphate, respectively (2).

In the hay samples analyzed in 1957 from a nine year old ley the timothy content was $2,38,57$, and 51 per cent for the $0, \mathrm{P}, 2 \mathrm{P}$, and $3 \mathrm{P}$ treatments, respectively. The yields harvested in this year are recorded in Table 1 . The untreated soil appears to be quite depleted of available phosphorus, while the lowest application of superphosphate has been sufficient to produce only a yield which is about 60 per cent of that in the treatments $2 \mathrm{P}$ and $3 \mathrm{P}$. Both the latter treatments have been equal as regards the yields of dry matter. In the composition of the dry matter there seem, however, to be considerable differences. 
Table 1. Hay yield harvested in 1957

\begin{tabular}{|c|c|c|c|c|c|c|c|c|}
\hline \multirow{2}{*}{ Treatment } & \multirow{2}{*}{$\begin{array}{c}\text { Dry matter } \\
\mathrm{kg} / \mathrm{ha}\end{array}$} & \multirow{2}{*}{$\begin{array}{l}\text { Ash } \\
\%\end{array}$} & \multirow{2}{*}{$\begin{array}{l}\mathrm{Ca} \\
\%\end{array}$} & \multirow{2}{*}{$\begin{array}{l}\mathrm{Mg} \\
\% \text { \% }\end{array}$} & \multicolumn{2}{|c|}{ K } & \multicolumn{2}{|c|}{$\mathrm{P}$} \\
\hline & & & & & $\%$ & $\mathrm{~kg} / \mathrm{ha}$ & $\%$ & $\mathrm{~kg} / \mathrm{ha}$ \\
\hline 0 & 280 & 6.56 & 3.6 & 3.1 & 20.6 & 6 & 1.27 & 0.4 \\
\hline $\mathbf{P}$ & 5130 & 4.87 & 2.0 & 1.7 & 18.6 & 95 & 0.96 & 4.9 \\
\hline $2 \mathrm{P}$ & 7390 & 4.96 & 2.3 & 2.6 & 16.1 & 119 & 1.69 & 12.5 \\
\hline $3 \mathrm{P}$ & 7350 & 3.78 & 2.2 & 2.1 & 12.5 & 92 & 1.85 & 13.6 \\
\hline L.S.D. $5 \%$ & 370 & 0.65 & 0.5 & 0.5 & 2.8 & 13 & 0.13 & 0.6 \\
\hline
\end{tabular}

The ash content of the hay from the plots fertilized with $300 \mathrm{~kg} / \mathrm{ha}$ of superphosphate is distinctly lower than that from the treatments with $200 \mathrm{~kg} / \mathrm{ha}$, or $100 \mathrm{~kg} / \mathrm{ha}$. In part, this may be explained by the fact that the hay in the $3 \mathrm{P}$ - plot is extremely poor in potassium. Its magnesium content also tends to be a little lower than that of the 2P-hay. All the samples collected from the treated plots appear to be fairly rich in magnesium whereas their calcium content is low.

The data for the potassium in the yield show that the annual application of potash fertilizer may be insufficient for the needs of a crop produced by $300 \mathrm{~kg} / \mathrm{ha}$ of superphosphate. It has been able to take up only about $90 \mathrm{~kg} / \mathrm{ha}$ of potassium or significantly less than the crop produced by $200 \mathrm{~kg} / \mathrm{ha}$ of superphosphate.

The phosphorus content of the hay increases with an increase in the amounts of superphosphate applied; the low hay yield from the untreated plot forms an exception. The difference between the $3 \mathrm{P}$ and $2 \mathrm{P}$ treatments is markedly lower than that between the treatments $2 \mathrm{P}$ and $\mathrm{P}$. The former is, however, sufficient to make the phosphorus yield from the $3 \mathrm{P}$ plot a little higher than the amount of phosphorus taken up from the $2 \mathrm{P}$ plot. The phosphorus content of the hay treated with $100 \mathrm{~kg} / \mathrm{ha}$ of superphosphate is extremely low, only about one half of that in the hay produced by $300 \mathrm{~kg} / \mathrm{ha}$ of superphosphate. Even the latter figure, $1.85 \mathrm{~g}$ $\mathrm{P}$ per kilogram of hay dry matter, is lower than the phosphorus content of hay of good quality.

In 1957 the experimental plots $\mathrm{P}, 2 \mathrm{P}$, and $3 \mathrm{P}$ received 8,16 , and $24 \mathrm{~kg} / \mathrm{ha}$ of superphosphate-P, respectively. Provided that all the phosphorus in the harvested hay yields originated from the fertilizer, the uptake of superphosphate phosphorus would correspond to about 60 per cent in plot $\mathrm{P}$, to about 80 per cent in plot $2 \mathrm{P}$, and to about 55 per cent in plot $3 \mathrm{P}$.

In order to test whether there are any marked differences in the phosphorus composition of the hay samples, a simple fractionation was performed. The following results were obtained:

$\begin{array}{lccccc} & \mathrm{P} \mathrm{mg} / \mathrm{g} \text { in hay samples from the treatments } \\ & 0 & \mathrm{P} & 2 \mathrm{P} & 3 \mathrm{P} & \mathrm{L} . \mathrm{S} . \mathrm{D} .5 \% \\ \text { inorganic } \mathrm{P} & 0.45 & 0.47 & 1.05 & 1.15 & 0.14 \\ \text { organic P, acid soluble } & 0.29 & 0.30 & 0.37 & 0.37 & 0.09 \\ \text { acid insoluble } & 0.48 & 0.22 & 0.27 & 0.30 & 0.06 \\ \mathrm{P} \text { in ethanol extract } & 0.03 & 0.03 & 0.03 & 0.04 & 0.01\end{array}$


Table 2. Potassium. calcium, and magnesium in the peat samples (Expressed as ppm of dry matter)

\begin{tabular}{|c|c|c|c|c|c|c|c|c|}
\hline \multirow{2}{*}{ Treatment } & \multicolumn{2}{|c|}{$\mathrm{pH}$} & \multicolumn{3}{|c|}{ Extractable } & \multicolumn{3}{|c|}{ Total } \\
\hline & $\mathrm{H}_{2}$ & $\mathrm{KCl}$ & K & $\mathrm{Ca}$ & $\mathrm{Mg}$ & K & $\mathrm{Ca}$ & $\mathrm{Mg}$ \\
\hline 0 & 4.2 & 4.1 & 560 & 5840 & 1210 & 4400 & 7400 & 4500 \\
\hline $\mathrm{P}$ & 4.4 & 4.2 & 210 & 6430 & 1560 & 3800 & 8000 & 4900 \\
\hline $2 \mathrm{P}$ & 4.5 & 4.2 & 160 & 7220 & 2000 & 3700 & 9100 & 5500 \\
\hline $3 \mathrm{P}$ & 4.5 & 4.2 & 150 & 7220 & 1810 & 3500 & 9100 & 5300 \\
\hline L.S.D. $5 \%$ & 0.2 & 0.1 & 30 & 1040 & 500 & 700 & 1300 & 600 \\
\hline
\end{tabular}

With the exception of the high amount of acid insoluble organic phosphorus in the 0 -hay, there seem to be no marked differences in the organic phosphorus fractions of these samples. The inorganic phosphorus content of the 0-hay and P-hay are equal, and so are the corresponding figures for $2 \mathrm{P}$-hay and $3 \mathrm{P}$-hay.

The botanical composition of the hay samples from the variously treated plots was not equal. An explanation for the differences in the phosphorus content of the hay may therefore be found in the different ability of various plants to take up phosphorus. This, however, seems to be unimportant in the case in question. The timothy plants were also analyzed separately, and their phosphorus contents were found to be equal to the corresponding figures for the mixed hay samples.

\section{Soil analyses}

The total nitrogen content of soil organic dry matter was equal in all the treatments and amounted to $3.5 \%$. The ash content varied from 37 to $40 \%$, but the differences were not significant. The weight of volume was about 0.5 in all the samples.

According to the data in Table 2 there seems to be some tendency to higher $\mathrm{pH}$-values in the samples from the plots treated with superphosphate. All the samples are, however, distinctly acid in spite of the fairly high calcium content. It is of interest to note that the $\mathrm{pH}$-values measured in the $\mathrm{KCl}$-suspension are only slightly lower than the corresponding values measured in water suspension.

The different phosphorus treatment in the course of 34 years has resulted in differences in the potassium condition of the peat soil. Only the untreated plots may be said to be fairly rich in available potassium; in all the other plots the figures for extractable potassium are low. Apparently the potassium annually introduced into the soil has been almost completely taken up by the plants in the plots treated with phosphate. The figures for "total" potassium are, owing to the claying, of an entirely different class of magnitude, but even in these data some slight tendency to lowering with an increase in the phosphate treatment may be found. The contents of extractable and "total" calcium and magnesium, on the other hand, seem to be somewhat higher in the treated plots $2 \mathrm{P}$ and $3 \mathrm{P}$ than in the untreated one.

The data in Table 3 show in the soil samples a higher content of total phosphorus the higher the treatment with superphosphate has been during the experimental 
Table 3. Total, inorganic and organic phosphorus in the peat samples

\begin{tabular}{ccccc}
\hline \multirow{2}{*}{ Treatment } & Total P & Inorganic $\mathrm{P}$ & \multicolumn{2}{c}{ Organic P } \\
\cline { 3 - 5 } & $\mathrm{ppm}$ & $\mathrm{ppm}$ & $\mathrm{ppm}$ & $\%$ of total P \\
\hline & 1030 & 240 & 790 & 77 \\
$\mathrm{P}$ & 1180 & 330 & 850 & 72 \\
$2 \mathrm{P}$ & 1340 & 390 & 950 & 71 \\
$3 \mathrm{P}$ & 1580 & 550 & 1030 & 65 \\
\hline L.S.D. 5\% & 80 & 40 & 60 & 3 \\
\hline
\end{tabular}

period. This is not only due to differences between the contents of inorganic phosphorus: in the figures for organic phosphorus a marked increase with the increase in the superphosphate application may also be observed.

It is not, of course, justifiable to conclude that the differences between the data for the treated soils and those for the untreated soil would represent the actual accumulation of fertilizer phosphorus in this soil. It may nevertheless be of interest to examine the differences caused by the application of superphosphate for 34 years at various rates. The following figures are obtained:

\begin{tabular}{cccc} 
Total superphosphate-P & \multicolumn{3}{c}{ P ppm in soil more than in the untreated plot } \\
applied & total & inorganic & organic \\
$\mathrm{P}=270 \mathrm{ppm}$ & 150 & 90 & 60 \\
$2 \mathrm{P}=540 \mathrm{ppm}$ & 310 & 150 & 160 \\
$3 \mathrm{P}=810 \mathrm{ppm}$ & 550 & 310 & 240
\end{tabular}

The differences in the total phosphorus of the treated and untreated plots correspond to 55-60 per cent of the fertilizer phosphorus in plots $\mathrm{P}$ and $2 \mathrm{P}$, and to almost 70 per cent in the $3 \mathrm{P}$-plot. About 40 to 50 per cent of the differences is due to the organic phosphorus.

Since there is no reason to suppose that any washing out of phosphorus would have occurred from this soil, the differences between the total amounts of phosphorus in the fertilizer and the corresponding increase in the soil represent phosphorus taken up by the harvested crops. These quantities are 120, 230, and 260 ppm of phosphorus for the treatments $\mathrm{P}, 2 \mathrm{P}$, and $3 \mathrm{P}$, respectively. A comparison of these figures with the phosphorus content of the hay yield harvested in 1957 indicates that either the phosphorus uptake of the crop plants has been lower in the previous years, or the plants have been compelled to resort to soil phosphorus in a considerable degree.

Even in the untreated plot the amount of inorganic phosphorus is not negligible. Yet the ley plants were able to take up only a very low quantity of phosphorus from these plots which indicates that the phosphorus is very strongly retained by the soil. The availability of phosphorus in the variously treated soils was studied in more detail with chemical methods and a plant experiment.

First a simple pot experiment was performed in which the phosphorus uptake from the soil samples by two successive crops of turnip rape seedlings was studied. The method was as follows: 
Table 4. Uptake of phosphorus by turnip rape seedlings, $\mathrm{P} \mathrm{mg} / \mathrm{pot}$

\begin{tabular}{cccc}
\hline & First crop & Second crop & Total \\
\hline Quartz sand & 1.79 & 1.68 & 3.47 \\
Sample 0 & 2.42 & 1.58 & 4.00 \\
P & 2.70 & 1.72 & 4.42 \\
2P & 3.38 & 1.87 & 5.25 \\
3P & 4.81 & 2.85 & 7.66 \\
In seeds & 2.14 & 2.14 & 4.28 \\
\hline L.S.D. 5\% & 0.21 & 0.19 & 0.22 \\
\hline
\end{tabular}

$50 \mathrm{~g}$ air dry sample and $50 \mathrm{~g}$ quartz sand were mixed, put into a Neubauer-dish and moistened with $80 \mathrm{ml}$ of a solution which contained $20 \mathrm{mg}$ potassium, $7 \mathrm{mg}$ nitrogen, $5 \mathrm{mg}$ magnesium and about $6 \mathrm{mg}$ sulphur as potassium nitrate and magnesium sulphate. The surface was covered with $150 \mathrm{~g}$ of moistened quartz sand in which 100 seeds of turnip rape were sown. They were grown under artificial light for 4 weeks and harvested. Also the roots were sieved for analysing. Another crop was sown in the same soil samples and similarly treated. The seedlings with roots were analyzed for total phosphorus. A blank test was performed with pure quartz sand treated with the same amounts of potassium, nitrogen, magnesium and sulphur as the peat samples.

The results in Table 4 show that the amount of phosphorus taken up by the turnip rape seedlings is the higher the more intensive the treatment with superphosphate has been. The first crop was able to get more phosphorus even from the untreated sample than was contained in the seed. The second crop, however, was poorer than the seeds in phosphorus, which was also the case with the second crop in the treatments $\mathrm{P}$ and $2 \mathrm{P}$. The dry matter yields of the second crop were only a little lower than those of the first crop, but the phosphorus yields were far lower.

The actual uptake of phosphorus from the soil samples may be calculated on the basis of the blank values or on the basis of the phosphorus in seeds. In the former case somewhat higher results are obtained, since the seedlings which grew in pure quartz sand were not able to take up all the seed phosphorus moved into the sand. If the results are expressed as $\mathrm{P}$ ppm of soil the following figures represent the plant available phosphorus in this experiment calculated on the basis of the seed phosphorus (a) and blank test (b):

\begin{tabular}{crrrr} 
Treatment & \multicolumn{2}{c}{ I crop } & I + II crops \\
& a & b & a & b \\
0 & 6 & 13 & -6 & 11 \\
P & 11 & 18 & 3 & 11 \\
$2 \mathrm{P}$ & 25 & 32 & 19 & 36 \\
3P & 53 & 60 & 68 & 84
\end{tabular}

In every case the amounts of phosphorus taken up from the untreated samples have been very low or even negative. The data for the samples from treatment $\mathrm{P}$ are not significantly higher than those from the untreated one, whereas the figures for the 3P-treatment represent another class in size.

Similar results were obtained when the soil samples were extracted with $0.03 \mathrm{~N}$ ammonium fluoride at $\mathrm{pH}$ 3. These data are recorded in Table 5. The table also 
Table 5. Phosphorus condition in the variously treated soil samples

\begin{tabular}{cccc}
\hline Treatment & $\begin{array}{c}\text { P soluble } \\
\text { in acid } \\
\mathrm{NH}_{4} \mathrm{~F} \\
\mathrm{Ppm}\end{array}$ & $\begin{array}{c}\text { Exchange- } \\
\text { able P* }\end{array}$ & $\begin{array}{c}\text { "P in soil } \\
\text { solution }\end{array}$ \\
\hline 0 & 2.6 & 48 & $\mathrm{mg} / 1$ \\
\hline $\mathrm{P}$ & 3.6 & 74 & 0.04 \\
$2 \mathrm{P}$ & 6.3 & 129 & 0.06 \\
$3 \mathrm{P}$ & 7.2 & 269 & 0.10 \\
\hline L.S.D. $5 \%$ & 2.6 & 33 & 0.43 \\
\hline
\end{tabular}

contains the results from the attempt to determine the phosphorus capacity and and intensity factors for these samples by the TERÄsvuORI method. The former quantity was determined by an extraction of the samples with a $0.1 \mathrm{~N}$ mixture of potassium hydroxide and potassium carbonate solutions in a ratio of 1 to 100 for 18 hours, in Table 5 it is represented by the figures under "Exchangeable $P$ n. The latter quantity was calculated according to Freundlich's adsorption equation on the basis of data for the retention of phosphorus from solutions at two different phosphorus concentrations. These figures are reported in the column $» \mathrm{P}$ in soil solution».

Both the intensity and the capacity factors are low for the samples from the 0 - and P-treatments, and no significant differences exist between these samples in this respect. Somewhat higher values are found in the $2 \mathrm{P}$-treatment, but only the 3P-treatment shows a fairly good phosphorus condition.

\section{Discussion}

On the basis of the dry matter yields harvested in 1957 and also in the previous years, it does not seem to be profitable to use in this peat soil an annual superphosphate dressing higher than $200 \mathrm{~kg} / \mathrm{ha}$. This result agrees with the data reported by LUNDBLAD (5) from a 20-years field trial on fen soil carried out according to a plan which differs from the present one in that instead of $300 \mathrm{~kg} / \mathrm{ha}$ of superphosphate $400 \mathrm{~kg} / \mathrm{ha}$ is used. In the Swedish experiment an annual dressing with ammonium sulphate was also applied.

Probably owing to a lower acidity and a higher calcium content in the Swedish peat soil its phosphorus seems to be better available to the plants than that in the Leteensuo soil. The yield of the untreated plot in the Swedish trial remains at least fairly satisfactory, whereas in the Finnish trial it dropped as early as in the eleventh year to about ten per cent of the yield produced by $200 \mathrm{~kg} / \mathrm{ha}$ of superphosphate.

The fact that the untreated plot in the present trial has during the 34 experimental years been depleted of available phosphorus is also revealed by the biological and chemical soil tests. These showed, however, that the phosphorus condition in 
the plot annually treated with $100 \mathrm{~kg} /$ ha of superphosphate is also very poor, and often not distinctly better than that in the untreated soil. The annual application of $200 \mathrm{~kg} /$ ha of superphosphate has been able to maintain a more satisfactory rate of available phosphorus in the soil, but only the treatment with $300 \mathrm{~kg} / \mathrm{ha}$ has resulted in markedly higher test values than those for the lower treatments.

Since, despite the fact that the amounts of available nitrogen (4) and phosphorus are significantly higher in the $3 \mathrm{P}$-plots than in the $2 \mathrm{P}$-plots, the yields from these treatments are equal, it seems possible that there are some factors which prevent the full utilization of these sources of nutrients in the $3 \mathrm{P}$-plots. The extremely low potassium content of the hay from these plots suggests that one of the reasons may be an insufficient supply of potassium. The soil tests also showed a low content of easily extractable potassium in the soil of this treatment.

The problem is, however, not all that simple. The dry matter yields in the treatments $2 \mathrm{P}$ and $3 \mathrm{P}$ have been almost equal during the experimental period. There are no analytical results available which would indicate that the potassium content of the crop had been higher in the $3 \mathrm{P}$-treatment than in the $2 \mathrm{P}$-treatment, or that more washing out of potassium would have occurred from the $3 \mathrm{P}$-plot. Thus, it can not be claimed that the crops in the 3P-plots had depleted the potassium sources during the experimental period and were not able to satisfy their need of potassium from the annual dressing as well as the crops in the $2 \mathrm{P}$-plots. It is quite possible that the very low potassium content in the $3 \mathrm{P}$-hay is only accidental, since in the data reported by LUNDBLAD (5) the potassium content of hay varied markedly even in the same treatment from year to year. The fact that the yields in both the treatments were fairly high, particularly for a nine year old ley, indicates that there was no fatal lack of potassium. Probably the climatic factors and also the botanical composition of the ley prevent the better utilization of the available phosphorus and nitrogen in the $3 \mathrm{P}$-plots. It may, however, be profitable to apply a somewhat higher potassium dressing to all the treatments, since the test values for the soils in the $\mathrm{P}-, 2 \mathrm{P}-$, and $3 \mathrm{P}$-plots were not high.

\section{$S u m m$ ary}

The effect on a fen soil of superphosphate applied for 34 years at the annual rates of $0,100,200$, and $300 \mathrm{~kg} / \mathrm{ha}$ was studied. The material consisted of samples from a field trial at the Leteensuo Experiment Station. The soil samples from the ploughing layer were collected in autumn 1956, and the hay samples from the crop harvested in 1957 .

The hay yields from the treatments with 200 or $300 \mathrm{~kg} / \mathrm{ha}$ of superphosphate were about $7400 \mathrm{~kg} / \mathrm{ha}$, and the phosphorus content of the hay 1.69 and 1.85 per cent, respectively. The treatment with $100 \mathrm{~kg} /$ ha of superphosphate yielded only about $5100 \mathrm{~kg} / \mathrm{ha}$ of hay dry matter with a very low phosphorus content, 0.96 per cent. The yield from the untreated plots was almost negligible.

Also the biological and chemical soil tests showed that the untreated soil was almost depleted of available phosphorus. The phosphorus conditions in the soil 
annually treated with $100 \mathrm{~kg} /$ ha of superphosphate were not significantly better than in the untreated soil. An annual anplication of $200 \mathrm{~kg} / \mathrm{ha}$ of superphosphate was able to maintain a more satisfactory rate of available phosphorus in the soil, but only the treatment with $300 \mathrm{~kg} / \mathrm{ha}$ of superphosphate resulted in markedly higher test values than those for the lower treatments.

The total phosphorus content of the soil was the higher the larger the amount of superphosphate applied. About 40 to 50 per cent of the differences between the total phosphorus content of the treated and untreated samples was due to organic phosphorus.

The potassium content of the hay was the lower the higher the superphosphate treatment. The hay from the treatment with $300 \mathrm{~kg} / \mathrm{ha}$ of superphosphate contained only 1.25 per cent potassium. The possibility that potassium was a minimumfactor in this treatment was discussed.

\section{REFERENCES}

(1) Bray, R. H. \& Kurtz, L. T. 1945. Determination of total, organic, and available forms of phosphorus in soils. Soil Sci. 59: $39-45$.

(2) Hirvensalo, U. E. 1947. Koe nousevilla fosfaattimäärillä Suoviljelysyhdistyksen Leteensuon koeasemalla vuosina 1923 -46. Suovilj. yhd. vuosik. 51: 42-50.

(3) KAIFA, A. 1952. Observations on the effect of nitrogen and phosphorus upon the humification of straw. Acta Agr. Fenn. 78,

$(4) \longrightarrow$ 1958. Effect of superphosphate on the mobilization of nitrogen in a peat soil. J. Sci. Agr. Soc. Finland 30: 114-124.

(5) LundBlad, K. 1952. Gödslingens inverkan på vegetation och mark. (Summary: The influence of fertilizers on vegetation and soil) Statens Jordbr. förs. Medd. Nr. 42.

(6) Teräsvuori, A. 1954. Uber die Anwendung saurer Extraktionslösungen zur Bestimmung des Phosphordüngerbedarfs des Bodens, nebst theoretischen Erörterungen über den Phosphorzustand des Bodens. Publ. Staatl. Landw. Versuchsw. Finland Nr 141.

(7) ValdmaA, K. 1958. The action of phosphate fertilization on the properties of a peat soil humus. Acta Agr. Scand. 8: 216-225.

S E L OS T U S:

SUPERFOSFAATTILANNOITUKSEN VAIKUTUKSESTA TURVEMAAHAN

ARMI KAILA

Yliopiston maanviljelyskemian laitos, Helsinki

Tutkimuksen kohteena oli Leteensuon koeaseman «Koe enenevillä fosforihappomäärillä mutasuolla» . Analysoitiin koejäsenet, jotka olivat saaneet vuodesta 1923 alkaen vuotuislannoituksena, 0, 100,200 tai $300 \mathrm{~kg} /$ ha superfosfaattia sekä saman määrän kalisuolaa, joka on eri vuosina vaihdellut 100 $300 \mathrm{~kg} / \mathrm{ha}$. Maanäytteet otettiin syksyllä 1956 muokkauskerroksesta ja heinänäytteet seuraavan kesän sadosta, joka korjattiin yhdeksännen vuoden nurmesta.

Suurimmilla superfosfaatin määrillä saatu heinäsato oli yhtä suuri, noin $7400 \mathrm{~kg} / \mathrm{ha}$, mutta heinăn fosforin pitoisuus oli $200 \mathrm{~kg}: n$ superfosfaattilannoituksella $1.69 \%$ ja $300 \mathrm{~kg}$ :n lannoituksella $1.85 \%$. $100 \mathrm{~kg}$ superfosfaattia tuotti vain noin $5100 \mathrm{~kg} / \mathrm{ha}$ heinäă, jonka fosforin pitoisuus oli matala, $0.96 \%$. Lannoittamattoman koejäsenen sato oli mitätön. 
Biologisin ja kemiallisin menetelmin saadut analyysitulokset osoittivat, että lannoittamattoman koejäsenen maa oli täysin köyhtynyt käyttökelpoisesta fosforista. Vuotuinen $100 \mathrm{~kg} / \mathrm{ha}$ superfosfaattia ei ollut pystynyt pitämään maan fosforitilannetta paljonkaan parempana. $200 \mathrm{~kg} / \mathrm{ha}$ näytti ylläpitävän jo tyydyttävämpää fosforitilannetta, mutta vasta $300 \mathrm{~kg} /$ ha riitti takaamaan huomattavasti lannoittamattomasta maasta saatuja tuloksia paremmat testien arvot.

Maan kokonaisfosforin pitoisuus oli sitä suurempi, mitä runsaampi oli vuotuinen fosforilannoitus. Noin $40-50 \%$ lannoitettujen ja lannoittamattoman koejäsenen kokonaisfosforin määrien erotuksesta oli orgaanista fosforia.

Heinän kaliumin pitoisuus oli sitä matalampi, mitä suurempi fosforilannoitus oli annettu. $300 \mathrm{~kg} / \mathrm{ha}$ saaneen koejäsenen heinässä oli vain $1.25 \%$ kaliumia. 